\title{
Anatomical Study of Variations in the Origin of Axillary Artery Branches and Its Clinical Emphasis
}

\author{
Suman Tiwari ${ }^{1}$, M Khizer Hussain Afroze ${ }^{2}$ \\ ${ }^{1}$ Associate Professor, MVJ Medical College \& Research Hospital, Bangalore, India, ${ }^{2}$ Assistant Professor, MVJ Medical College \& Research Hospital, \\ Bangalore, India.
}

\section{Abstract}

Introduction: Axillary artery, one of the most important arteries of the upper limb is gaining increasing interest in the cardiac and cardiopulmonary bypass surgeries. The present study describes the number of branches arising from axillary artery and variations in their origin. Subjects and Methods: 40 upper limbs from 20 adult embalmed human cadavers of both the sexes were studied by dissection method at the Department of Anatomy, MVJ Medical College, and Bangalore. Results: The number of branches arising from axillary artery varied from 4 -7.The most common variation in the present study was observed in the origin of subscapular artery(15\%), followed by posterior circumflex humeral (10\%), anterior circumflex humeral \& lateral thoracic (7.5\% each) and superior thoracic artery (2.5\%). Any type of variation in the origin of thoracoacromial artery was not found in the present study. Conclusion: Knowledge of variations in the origin of axillary artery branches is of immense significance to anatomists, anaesthetists, cardiovascular and orthopaedic surgeons during surgical exploration of axilla, during flap or reconstructive surgeries, shoulder dislocation and for radiologists during angiography.

Keywords: Axillary artery, lateral thoracic artery, posterior circumflex humeral artery, subscapular artery.

Corresponding Author: Dr. M Khizer Hussain Afroze, Assistant Professor, Department of Anatomy, MVJ Medical College \& Research Hospital, Hosakote, Bangalore-562114, Karnataka, India.

Email: drafroze.homoeo@gmail.com

Received: January 2020

Accepted: January 2020

\section{Introduction}

Variations in the arteries of the upper extremities are quite common and may occur at the level of axilla, arm, cubital fossa and hand.

The axillary artery (AA), a continuation of subclavian artery, begins at the outer border of the first rib, and ends nominally at the inferior border of teres major where it becomes the brachial artery. Pectoralis minor crosses it and so divides it into three parts, first part (proximal), second part (posterior) and third part (distal) to the muscle. According to the classic description, axillary artery gives off six branches; first part giving rise to superior thoracic artery (STA), second part to thoracoacromial (TAA) and lateral thoracic (LTA) and the third part to subscapular (SSA), anterior circumflex humeral (ACHA) and posterior circumflex humeral arteries (PCHA). About $4 \mathrm{~cm}$ from the origin, subscapular artery divides into circumflex scapular (CSA) and thoracodorsal arteries. (TDA)

The alar thoracic (ATA) artery, an inconstant branch often arises from the second part of axillary artery and may supply fat and lymph nodes in the axilla. The lateral thoracic artery may be absent when it is replaced by lateral perforating branches of the intercostal arteries. In upto $30 \%$ of cases, the subscapular artery can arise from a common trunk with the posterior circumflex humeral artery. ${ }^{[1]}$

The number of branches arising from axillary artery is variable as there is no fixed pattern. The branches may arise independently from axillary artery; two or more of usual named branches may arise by a common trunk. ${ }^{[2]}$

One of the unusual branches of the axillary artery includes an accessory lateral thoracic artery. The branches of the third part of axillary artery are subject to great variations. The both circumflex arteries may arise from a common trunk, usually alone or rarely together with profunda brachii and muscular branches. Very rarely it may give rise to a common trunk, from which may arise the subscapular, anterior and posterior circumflex humeral, profunda brachii and ulnar collateral arteries. ${ }^{[3]}$

Variations in the axillary artery are significant during vascular surgeries Axillary artery is prone to damage during injuries like penetrating wounds, during traumatic dislocation of the shoulder. It is the artery for ligation during amputation procedures of the upper limb. Compression of the third part of axillary artery against the humerus may be necessary when profuse bleeding occurs. One of the most commonly performed extra anatomic bypasses by vascular surgeons in the present era is that of axillary artery. Branches of axillary artery are used for coronary artery 
bypass and other cardiovascular surgical procedures. They are also used to reduce old dislocations, especially when the artery is adherent to the articular capsule. [4] The present study is undertaken to know the incidence of variations in the origin of axillary artery branches and its Clinical Importance.

\section{Subjects and Methods}

Forty upper limbs of 20 adult embalmed human cadavers from south Indian population were studied irrespective of their sex. The specimens were obtained from the Department of Anatomy, MVJ Medical College, Bangalore. The gross dissection was done following the guidelines of Cunningham's manual. ${ }^{[5]}$ The loose connective tissue, fat $\&$ lymph nodes from the axilla were removed to expose its contents. The venae commitantes that come in the way were resected and axillary artery along with the vein were exposed. All the branches of axillary artery were traced. The total number of branches arising from axillary artery, their site of origin along with variations in the origin \& presence of any common trunk of origin were noted. The data obtained was analyzed and compared with that of previous studies.

\section{Results}

An observation concerning the number of branches and variations in the origin of branches from axillary artery was studied in 40 specimens. In $35(87.5 \%)$ specimens, the axillary artery gave 6 branches. The number of branches were found to be 4 in $1(2.5 \%), 5$ in $2(5 \%)$ and \& 7 in $2(5 \%)$ specimens.

The frequency distribution of variation in the origin of branches from axillary artery have been summarised in Table 1.

Table 1: Frequency distribution of variation in origin of axillary artery branches

\begin{tabular}{|c|c|c|c|}
\hline \multirow{2}{*}{$\begin{array}{c}\text { Axillary artery } \\
\text { branches }\end{array}$} & \multicolumn{3}{|c|}{ Origin } \\
\hline & $\begin{array}{c}\text { Normal } \\
\mathbf{n}(\%)\end{array}$ & $\begin{array}{c}\text { Variation } \\
\text { n }(\%)\end{array}$ & Comments \\
\hline $\begin{array}{l}\text { Superior } \\
\text { Thoracic Artery }\end{array}$ & $\begin{array}{l}39 \\
(97.5)\end{array}$ & $01(2.5)$ & $\begin{array}{l}\text { STA arising from 2nd part ( } \\
\text { Fig 1) }\end{array}$ \\
\hline $\begin{array}{l}\text { Thoracoacromial } \\
\text { Artery }\end{array}$ & $40(100)$ & $0(0)$ & - \\
\hline $\begin{array}{l}\text { Lateral Thoracic } \\
\text { Artery }\end{array}$ & $\begin{array}{l}37 \\
(92.5)\end{array}$ & $03(7.5)$ & $\begin{array}{l}\text { Arising } \\
\text { as common trunk with SSA } \\
\text { from 2nd part( } 2 \text { cases }) \text { - Fig } 2 \\
\text { as a branch from SSA from } \\
\text { 2nd part ( } 1 \text { case }) \text { - Fig } 3\end{array}$ \\
\hline $\begin{array}{l}\text { Subscapular } \\
\text { Artery }\end{array}$ & $34(85)$ & $06(15)$ & $\begin{array}{l}\text { Arising from 2nd part } \\
\text { as common trunk with LTA } \\
\text { ( } 2 \text { cases) giving LTA (1 } \\
\text { case) } \\
\text { as common trunk with PCHA } \\
\text { ( } 1 \text { case)-Fig } 4 \\
\text { along with the presence of } \\
\text { ATA ( } 1 \text { case)- Fig } 5 \\
\text { CSA arising as separate } \\
\text { branch from 3rd part ( } 1 \text { case) } \\
\text { - Fig } 6\end{array}$ \\
\hline $\begin{array}{l}\text { Anterior } \\
\text { Circumflex } \\
\text { Humeral Artery }\end{array}$ & $37(92.5)$ & $03(7.5)$ & $\begin{array}{l}\text { 1. arising as common trunk } \\
\text { with PCHA }\end{array}$ \\
\hline
\end{tabular}

\begin{tabular}{|l|l|l|l|}
\hline $\begin{array}{l}\text { Posterior } \\
\text { Circumflex } \\
\text { Humeral Artery }\end{array}$ & $36(90)$ & $4(10)$ & $\begin{array}{l}\text { 1. arising as common trunk } \\
\text { with ACHA (3 cases) Fig 2 } \\
\text { 2.arising as common trunk } \\
\text { with SSA (1 case) }\end{array}$ \\
\hline
\end{tabular}

The most common variation in the present study was observed in the origin of subscapular artery (15\%) followed by posterior circumflex humeral (10\%), anterior circumflex humeral \& lateral thoracic $(7.5 \%$ each) and superior thoracic artery $(2.5 \%)$. Thoracoacromial artery did not show any variation in its origin.

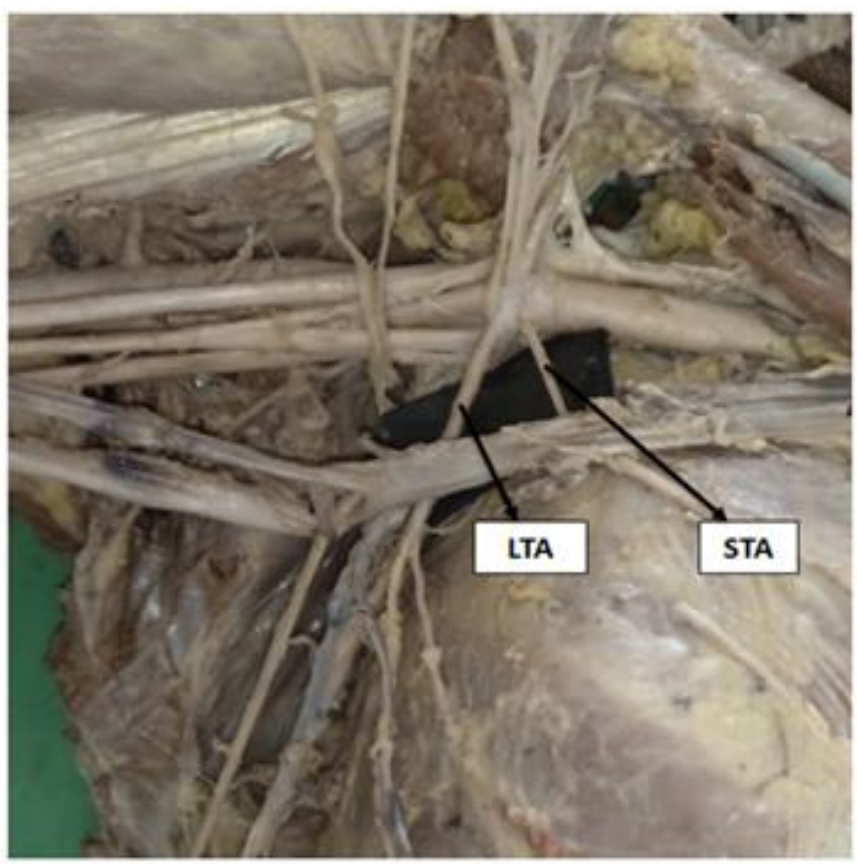

Figure 1: STA arising from $2^{\text {nd }}$ part of axillary artery

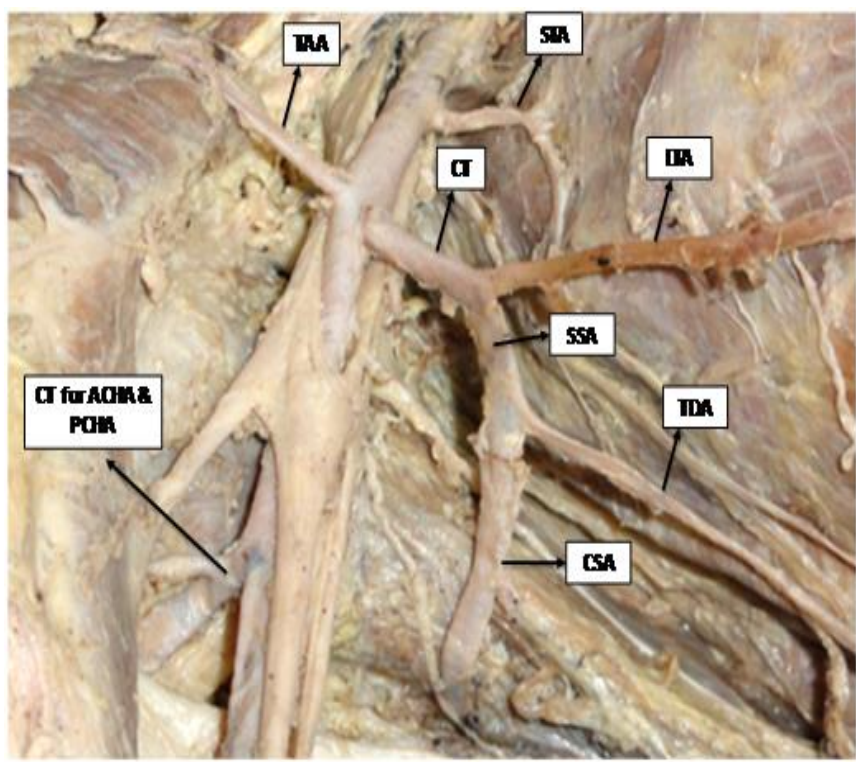

Figure 2: common trunk of LTA \& SSA from $2^{\text {nd }}$ part of AA, Common trunk for ACHA \& PCHA 


\section{Tiwari \& Afroze; Variations in the Origin of Axillary Artery Branches}

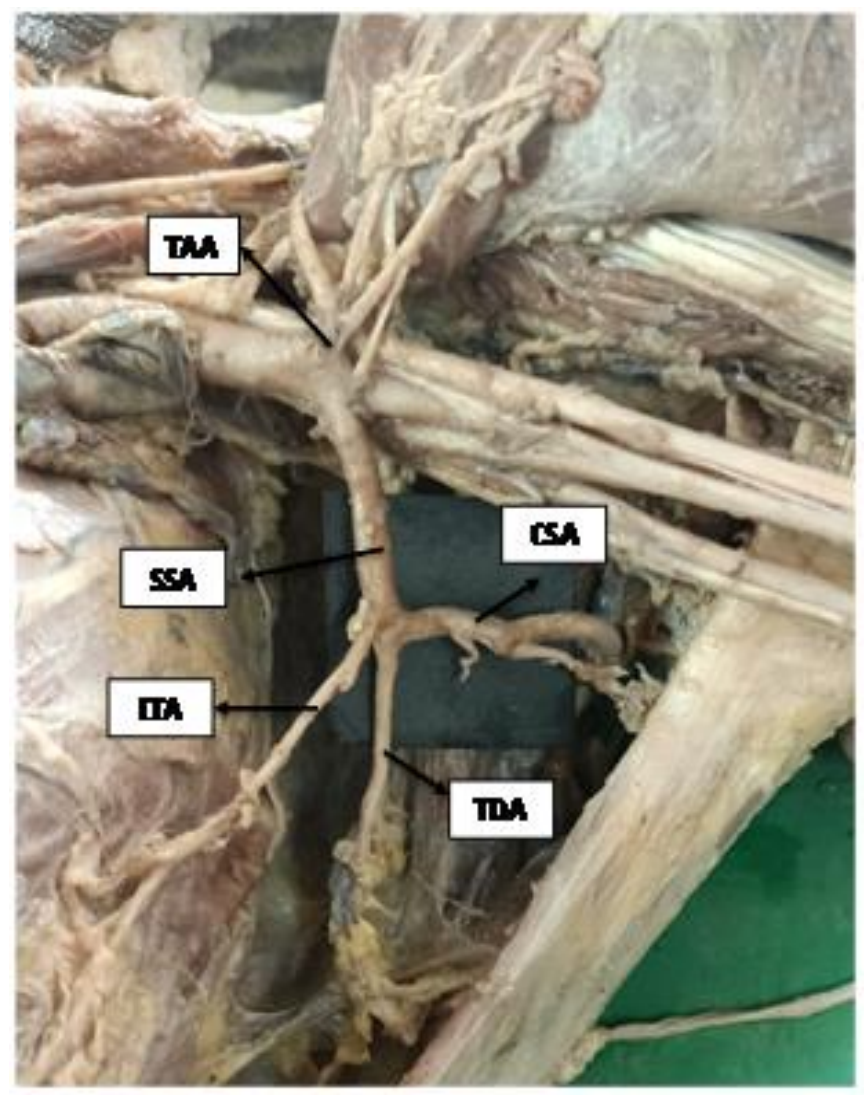

Figure 3: SSA arising from $2^{\text {nd }}$ part of AA \& giving rise to LTA

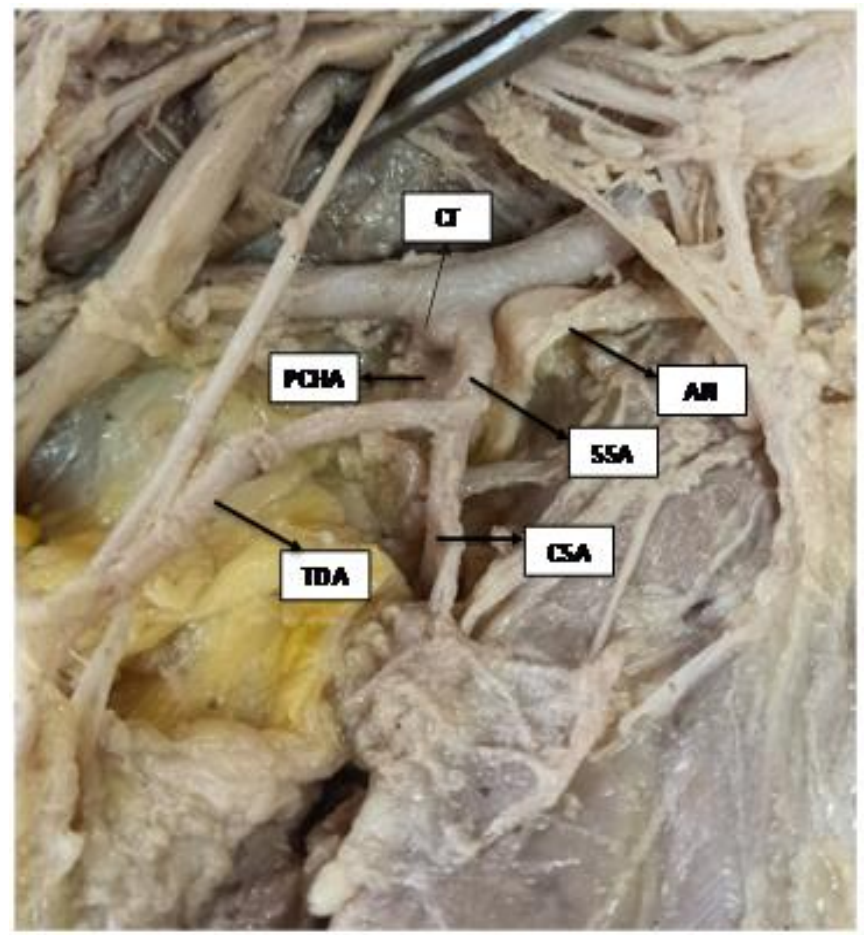

Figure 4: Common trunk of SSA \& PCHA arising from $2^{\text {nd }}$ part of AA

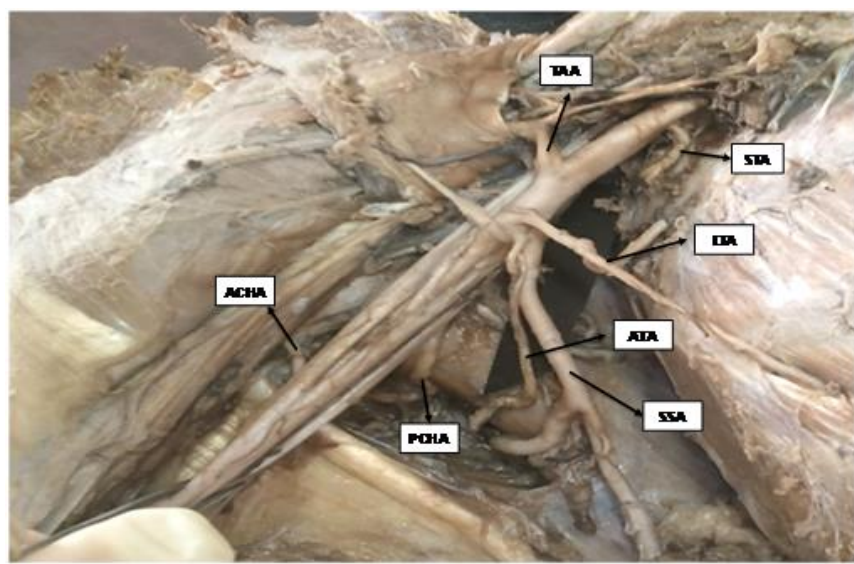

Figure 5: SSA arising from $2^{\text {nd }}$ part of AA along with the presence of ATA

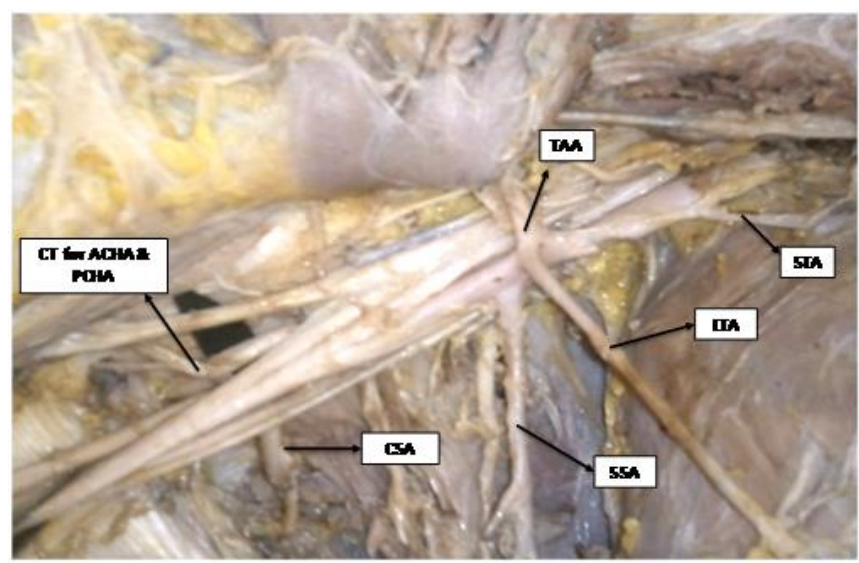

Figure 6: SSA arising from $2^{\text {nd }}$ part \& CSA originating directly from $3^{\text {rd }}$ part of $A A$

\section{Discussion}

The number of branches arising from axillary artery reported by different authors have been summarised in Table 2 .

Table 2: Number of branches arising from axillary artery

\begin{tabular}{|l|l|l|}
\hline Author & No. of limbs studied & Number of branches \\
\hline Degaris\&Swartley $^{[6]}$ & 512 & $5-11$ \\
\hline Huelke $^{[7]}$ & 178 & $2-7$ \\
\hline Astik $^{[4]}$ & 80 & $4-8$ \\
\hline Kanaka $^{[8]}$ & 60 & $5-8$ \\
\hline Present study & 60 & $4-7$ \\
\hline
\end{tabular}

De Garis and Swartley ${ }^{[6]}$, in their study, reported the most frequent number of branches arising from axillary artery to be 8 . In the present study, the most frequent encountered was 6.

In all the specimens studied, thoracoacromial artery arose from the $2^{\text {nd }}$ part of axillary artery. This correlates with the findings of $\mathrm{Pan}^{[9]}$ who had reported the origin of Thoracoacromial artery from $2^{\text {nd }}$ part of axillary artery in $100 \%$ of cases.

The mode of origin of Superior thoracic, Lateral thoracic, Subscapular \& Posterior Circumflex Humeral arteries by different authors have been compared \& summarized in Table 3. 
Table 3: Mode of origin of Superior thoracic, Lateral thoracic, Subscapular \& Posterior Circumflex Humeral arteries

\begin{tabular}{|c|c|c|c|c|c|}
\hline \multirow[b]{2}{*}{ Branch } & \multirow[b]{2}{*}{$\begin{array}{l}\text { Site } \\
\text { of } \\
\text { origi } \\
\text { n }\end{array}$} & \multicolumn{4}{|l|}{ Author } \\
\hline & & $\begin{array}{l}\text { Degaris\&swar } \\
\text { tley }^{[6]}\end{array}$ & $\begin{array}{l}\text { Huelk } \\
\mathrm{e}^{[7]}\end{array}$ & $\begin{array}{l}\text { Mohamma } \\
d^{[10]}\end{array}$ & $\begin{array}{l}\text { Prese } \\
\text { nt } \\
\text { study }\end{array}$ \\
\hline \multirow[t]{2}{*}{$\begin{array}{l}\text { Superior } \\
\text { thoracic } \\
\text { artery }\end{array}$} & $\begin{array}{l}\text { Direct } \\
\text { ly } \\
\text { from } \\
1^{\text {st }} \\
\text { part of } \\
\text { AA }\end{array}$ & $96.9 \%$ & $86.6 \%$ & $82 \%$ & $97.5 \%$ \\
\hline & $\begin{array}{l}2^{\text {nd }} \\
\text { part of } \\
\text { AA }\end{array}$ & - & $2.2 \%$ & & $2.5 \%$ \\
\hline $\begin{array}{l}\text { Lateral } \\
\text { thoracic } \\
\text { artery }\end{array}$ & $\begin{array}{l}\text { With } \\
\text { SSA }\end{array}$ & $1.2 \%$ & $14 \%$ & $6 \%$ & $5 \%$ \\
\hline $\begin{array}{l}\text { Subscap } \\
\text { ular } \\
\text { artery } \\
\end{array}$ & $\begin{array}{l}\text { From } \\
2^{\text {nd }} \\
\text { part }\end{array}$ & $5.1 \%$ & $15.7 \%$ & $16 \%$ & $15 \%$ \\
\hline \multirow{2}{*}{$\begin{array}{l}\text { Posterior } \\
\text { circumfl } \\
\text { ex } \\
\text { humeral } \\
\text { artery }\end{array}$} & $\begin{array}{l}\text { In } \\
\text { comm } \\
\text { on } \\
\text { with } \\
\text { SSA } \\
\end{array}$ & $1.4 \%$ & $15.2 \%$ & $22 \%$ & $2.5 . \%$ \\
\hline & $\begin{array}{l}\text { In } \\
\text { comm } \\
\text { on } \\
\text { with } \\
\text { ACH } \\
\text { A } \\
\end{array}$ & $15.8 \%$ & $11.2 \%$ & $16 \%$ & $7.5 \%$ \\
\hline
\end{tabular}

The most common variation was observed in the origin of subscapular artery from $2^{\text {nd }}$ part which are similar to the findings of Huelke ${ }^{[6]} \&$ Mohammad ${ }^{[10]}$

The present study showed the origin of alar thoracic artery from $2^{\text {nd }}$ part of axillary artery in $1(2.5 \%)$ specimen, similar kind of variation was reported by Samta ${ }^{[11]}$ in $6 \%$ specimens. Case with this kind of variation should be examined or operated carefully during surgeries involved in breast augmentation and mastectomy.

The embryological basis for the variations in the origin of axillary artery branches occurs due to deviation in the embryonic development of the vascular plexus of upper limb bud. The axial artery is derived from lateral branch of seventh cervical intersegmental artery and the proximal part of it formed the axillary and the brachial artery. Any abnormality during development results in an unusual branching pattern. Variations may occur due to an arrest at any stage of development of vessels of upper limb. This may be due to regression, retention, or reappearance of new vessels. ${ }^{[12]}$

According to Arey ${ }^{[13]}$, the unusual blood vessels may be due to the choice of unusual paths in the primitive vascular plexuses, persistence of vessels normally obliterated, disappearance of vessels normally retained, incomplete development and fusions and absorption of the parts usually distinct.

Such anomalous branching pattern may represent persisting branches of the capillary plexus of the developing limb buds and their unusual course may be a cause for concern to the vascular radiologists and surgeons, and may lead to complications in surgeries involving the axilla and pectoral region.

Knowledge of variations in the axillary artery branches is necessary during antegrade cerebral perfusion in aortic surgery, while treating the axillary artery thrombosis, using the medial arm skin flap, reconstructing the axillary artery after trauma, while treating the haematoma of axillary artery, while considering the branches of the axillary artery for the use of microvascular graft to replace the damaged arteries, creating the axillary-coronary bypass shunt in high risk patients, catheterizing or cannulating the axillary artery for several procedures, during surgical intervention of fractured upper end of humerus, and shoulder dislocations. The pulsations of axillary artery should be felt as it serves as an important landmark during clinical procedure such as brachial plexus block and subclavian vein puncture. Axillary - subclavian artery bypass is also becoming treatment of choice in subclavian artery occlusion. Variant common trunks from axillary artery can be considered for cannulation. ${ }^{[4,8]}$

\section{Conclusion}

Variations in the origin of branches of axillary artery are a common arterial variation of upper limb. The most common variation found in the present study was in the origin of subscapular artery (15\% of specimens) from axillary artery. Knowledge of these variations is important during surgical exploration of axilla for axillary tumours, axillary lymphadenectomy, while performing bypass between axillary and subclavian artery and treatment of aneurysm of axillary artery. Furthermore, these variations should be investigated by ultrasonography and contrast arteriography by the surgeons before planning for any surgeries in the region of axilla.

\section{Acknowledgement}

I sincerely thank our HOD, Department of Anatomy and principal of MVJ Medical College \& Research Hospital, Bangalore, for giving me permission to carry out the research work.

\section{Legends for Photos}

- AA-Axillary artery

- ACHA- Anterior circumflex humeral artery

- AN- Axillary nerve

- ATA- Alar thoracic artery

- CSA- Circumflex scapular artery

- CT-Common trunk

- LTA- Lateral thoracic artery

- PCHA- Posterior circumflex humeral artery

- SSA-Subscapular artery

- STA- Superior thoracic artery

- TAA- Thoracoacromial artery

- TDA- Thoracodorsal artery

\section{References}

1. Standring S. Gray's anatomy. Pectoral girdle, Shoulder region, Axilla. The Anatomical basis of clinical practice. 40th Ed., London: Elsevier Churchill Livingstone; 2008:821-22

2. . Hollinshed W H. Anatomy for surgeons in general surgery from Harper Book, 1958. 3.290-300.

3. Ronald A. Bergman, Adel K. Afifi, RyosukeMiyauchi. Axillary 


\section{Tiwari d Apraze; Variations in the Origin of Axillary Artery Branches}

Artery Opus II: Arteries. Cardiovascular system. Illustrated Encyclopedia of Human Anatomic Variation: 2006

4. Astik R Dave U. Variations in branching pattern of the axillary artery: a study in 40 human cadavers. J Vasc Bras. 2012; 11(1):12-17.

5. Romanes GJ. Cunningham's manual of practical anatomy. Volume 1. 15th ed. Oxford: ELBS; 1992. p. 29-31.

6. DeGaris CF, Swartley WB. The axillary artery in white and Negro stocks. American J Anat. 1928; 41:353-97.

7. Huelke DF. Variation in the origins of the branches of the axillary artery. Anat Rec. 1959; 135:33-41.

8. Kanaka S ThejaEluru R, Akbar Basha M, R Somasekhar R, G Kanchanalatha, K S Haniman. Frequency of Variations in Axillary Artery Branches and its Surgical Importance. International Journal of Scientific Study 2015 Vol 3(6):1-4.
9. P'an Ming-Tzu 1940 The origin of branches of the axillary artery in the Chinese. Am. J. Phys. Anthropology., 27 (2): 269279.

10. Mohammad A. Morphometric and analytic study of axillary artery course and itsbranchesTikrit Medical Journal 2007; 13(1):132-138.

11. Gaur S, Katariya SK, H Vaishnani, I N Wani, K V Bondre, G V Shah. A Cadaveric Study of Branching Pattern of the Axillary Artery. Int J Biol Med Res. 2012; 3(1): 1388-1391

12. Decker GAG, du plessis DJ, Lee McGregor. Shoulder joint. In: Synopsis of Surgical Anatomy. Mumbai, K. M. Varghese Company. 1986; 451.

13. Arey LB. Developmental Anatomy. 6th Ed., Philadelphia, W.B. Saunders. 1957; 375-375.

Copyright: () the author(s), 2020. It is an open-access article distributed under the terms of the Creative Commons Attribution License (CC BY 4.0), which permits authors to retain ownership of the copyright for their content, and allow anyone to download, reuse, reprint, modify, distribute and/or copy the content as long as the original authors and source are cited.

How to cite this article: Tiwari S, Afroze MKH. Anatomical Study of Variations in the Origin of Axillary Artery Branches and Its Clinical Emphasis. Acad. Anat. Int. 2020;6(1):05-09.

DOI: dx.doi.org/10.21276/aanat.2020.6.1.2

Source of Support: Nil, Conflict of Interest: None declared. 